\section{The Teaching Didactics of Álvaro Siza}

Pedro Luz Pinto

Dinâmia-Cet / ISCTE-IUL

\section{BUILDING A TEACHING METHOD}

Álvaro Siza Vieira (1933) began his training at the Architecture Department of the School of Fine Arts in Porto (EBAP) in 1949, one year after the 1st Congress of Portuguese Architects (1948), which became known as the congress of modern architects. There were two fine arts schools at the time in Portugal, in Porto and Lisbon (EBAP and EBAL), both with an equivalent curriculum that was coordinated by the state. Siza attended the course based on the "beaux arts" programs of $1932^{1}$, concluding the curricular part of his course in 1955 and presenting his final graduation design in $1965^{2}$. But by this time, Portuguese education in the arts had already switched to "modern" curricula (1952-57 Reform) ${ }^{3}$. The following year, having already seen some of his important works built, Siza began his career as assistant professor at the school in Porto.

\section{6-69: DRAWING AS “DESIRE FOR INTELLIGENCE”}

"There was a very thorough study of the analysis of the problems of a project, followed by a phase of synthesis, with this idea that knowing all the problems in question, this is the moment to start for the project. In addition, I did a first course like that, very committed (...). I concluded at the end of a year that the works were very balanced, that is to say, they were straightforward, there were no absurdities, but they were frustrating, most of them. There were differences, but the average was sad, it had no great interest. I thought it was not the right method, and the next year I did a completely different experiment, in the sense that the overall solution hypothesis was as much starting point as the study that gradually increased in density of all sorts of problems. Therefore the design accompanied the deepening of the problems and was sufficiently flexible and moldable to accompany this gradual deepening." Álvaro Siza, $2009^{4}$.

Álvaro Siza's teaching career thus began in 1965-66, with his admission as assistant professor of Architectural Composition II for the 4th year of the ESBAP ${ }^{5}$ architecture course. In his first teaching ventures, Siza experimented with application of the methods that Nuno Portas (1934) 6 was promoting at the time in Lisbon (ESBAL). This experimentation was based on an attempt to reduce the arbitrariness of the design act and to base it on analytical data that would enable successive evaluation of the process and the overall effectiveness of the result. The "Portas method" required an analysis-design sequence that made a clear separation between the initial research phase and the subsequent design phase.

However, Siza quickly abandoned this sequence, proposing alternatively a method that provided for a simultaneous analytical and intuitive convergence, which was developed by the parallel and non-hierarchical use of intuitive and rigorous means of representation: "exhaustive study was carried out simultaneously to the development of an idea, with a somewhat instinctive component and immediate enthusiasm that was then subjected to criticism (...) therefore the absorption, the understanding of everything that was at issue accompanied the development of the design and exposed the design to critical review and consequent alteration."

Siza went on to favor programs and working sequences that came 


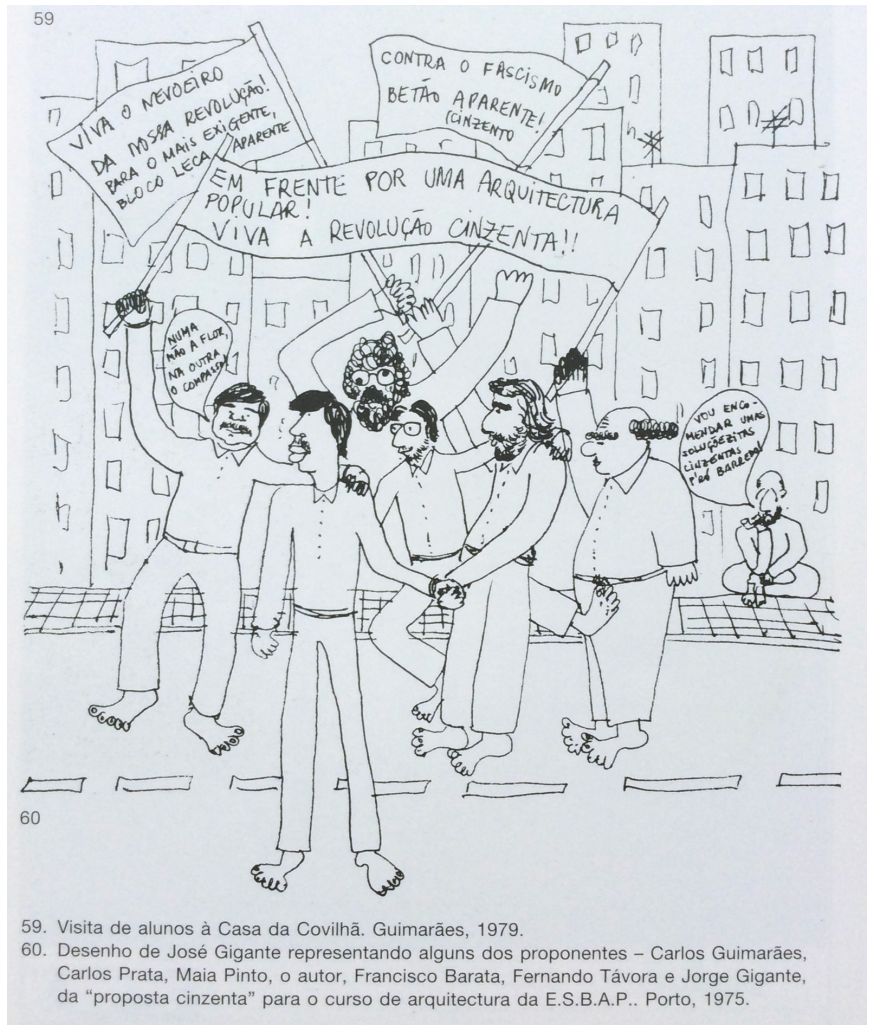

Figure 1. José Gigante, drawing (1975). Some of the "gray list" representatives Siza is on the sidewalk observing: "I will engender some little gray solutions for Barredo". In Fernando Távora (Lisboa: Blau, 1993) 42.

close to his atelier experience, proposing that his students perform similar work to what he was developing in his everyday practice ${ }^{8}$.

\section{6-69: DRAWING AS “DESIRE FOR INTELLIGENCE”}

In 1969, along with Pedro Ramalho (1937), Siza resigned as an ESBAP assistant professor, following a collective protest ${ }^{9}$ against contractual precariousness; the protest also took on a political stance. Carlos Ramos (1897-1969) ${ }^{10}$ had left the school administration in 1967 and had been replaced by António Cândido de Brito (19041989), who was closer to the dictatorial Salazar regime. The political situation was tumultuous, with the regime facing challenges in the upheavals of May 1968 and the student revolt of 1969. At the school, the "rationality" imposed by the Reform of 1957 came to be identified with "reactionary" ministerial oversight.

The general environment of protest and the expulsion of teachers gave rise to a deep crisis, jeopardizing the very continuity of the school. This turbulence would eventually lead to both schools being allowed to implement their own curricular "Experimental Regime", a situation that would occur in Porto between 1970, and to the withdrawal of the ministry in 1973. As part of this process, in late January 1970, the ministry authorized the re-admission of the former professors, and those professors who had resigned, among them Álvaro Siza, published a statement directed at the school ${ }^{11}$, which has come to be known as the "master guidelines for a scheme of thought", in which they proposed a set of structural principles:

- The school must "be based on the principle of teamwork, where criticism will be the norm within the creativity process"; this includes teachers and students having "functional autonomy" and the school being "separate from the Fine Arts";

- The re-foundation of the course should encompass two bases: (i) "the consolidation of the pedagogical work"; and (ii) "group structuring."

The pedagogical work was to be refined based on the existing structure in successive annual adjustments, and the "group" structure was designed to organize the teachers and students into joint committees.

Following this "experimentation", a number of teachers were reinstated, but not Siza, who did not consider the conditions as presented to be sufficient ${ }^{12}$. The first year of the experimental regime was to implement several of the suggestions of the "master guidelines"13, however the "experiment" met with growing internal opposition and the responsible ministry gradually blocked several structural aspects.

This tightening of the screw led to increasing instability, with ruptures between teachers and between teachers and students. There was a climate of political contestation, where all struggles, including disciplinary ones, became political ${ }^{14}$. In this period, Eduardo Souto de Moura (1952) (who was a student between 1970 and 1980) wrote: "the political awakening the system went through, the response of the Student Movement, and May 68, meant that the simple conception of architecture as an artefact was replaced by a more detailed analysis of a political-ideological order (...) with designing then becoming a complex cultural phenomenon. To draw means to experience the judgment that "all culture after Auschwitz is uncomfortable(...) is the conviction that reality can be used in support of the most brutal irrationality. It is fear, it is the 'silence of the poets', it is the legitimate despair of not drawing." ${ }^{15}$

\section{5-80: CONSTRUCTION AS INTELLIGENCE OF DESIRE}

The revolution of April 25, 1974 was to put an end to the authoritarian regime that had been in power since 1932 and the school, like the country, embraced freedom and advanced to elections and the redefinition of the curriculum.

The "yellow" list, supported by Álvaro Siza ${ }^{16}$, which advocated greater diversity of training in the 4th and 5th years of the course, won the February 1975 election by two votes, but rejected taking office in favor of the "gray" list, which was supported by, among others, Fernando Távora (1923-20059 and Alexandre Alves Costa (1939). The latter advocated a globally hierarchical curriculum based on design classes and "effective integration in reality."

One reason given for the winning list's refusal to take office was the school's urgent commitment to the SAAL Process (1974-1976) ${ }^{17}$, which provided the list members with an opportunity for real 


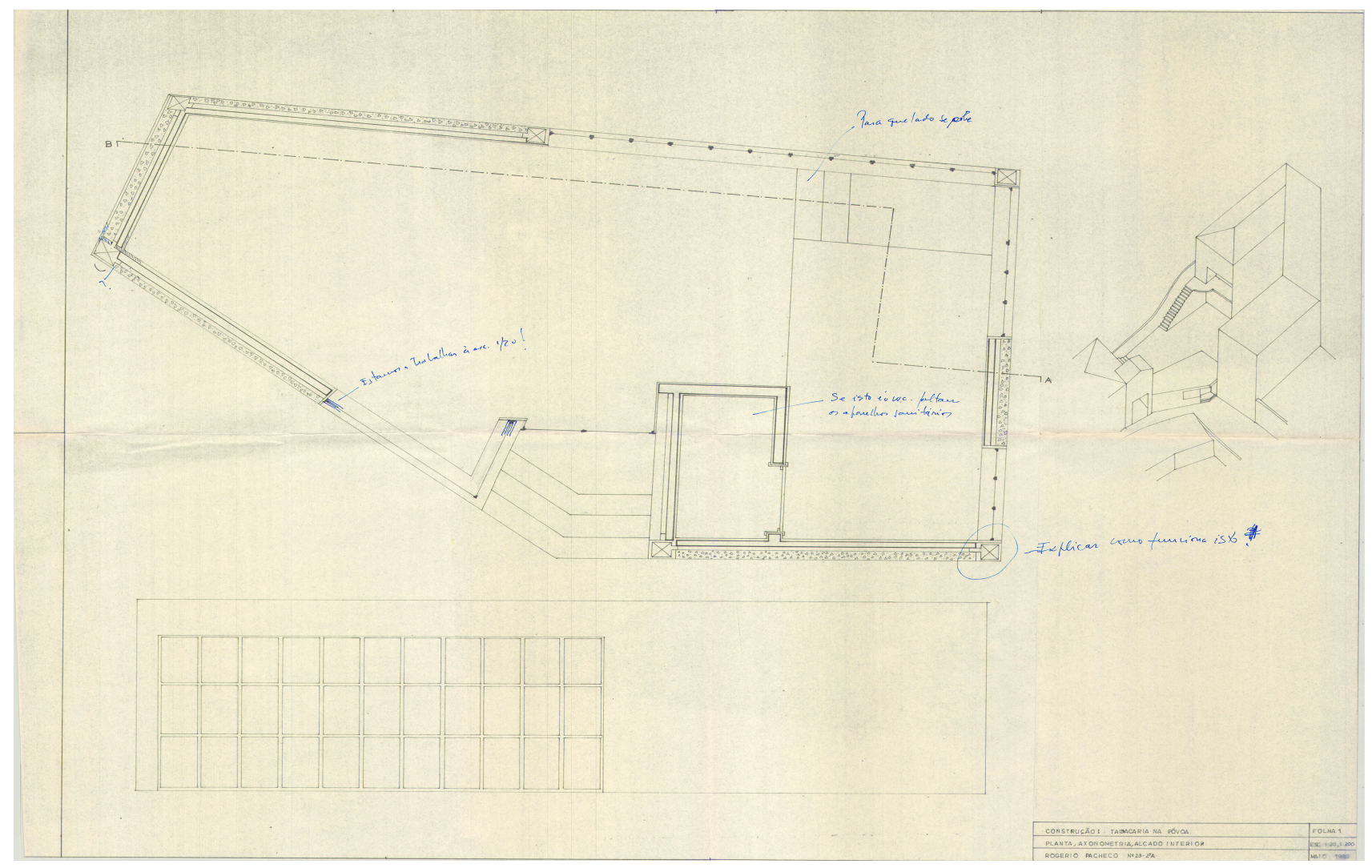

Figure 2. Rogério Pacheco, "Tabacaria na rua da Póvoa", Construções I (1979/80), Professor Álvaro Siza e Alcino Soutinho. FAUP-CDUA / CONST / 001. M2

involvement in the social and structural problem of providing housing for the poor.

As early as January 1975, the São Vítor Brigade, one of the units taking part in the SAAL program which was coordinated by Álvaro Siza, Domingos Tavares (1939), Francisco Guedes (1945) and several students ${ }^{18}$, proposed to the SAAL Coordinating Committee the involvement of teachers and students in the so-called Technical Brigades ${ }^{19}$.

This would allow for involvement of the school in real social problems and for it to experience participatory processes. Paradoxically, it also enabled a reconciliation process with the values of design and drawing, a situation for which, the work of Siza action, with his resolute engagement in the defense of disciplinary knowledge, was to be exemplary.

The end of the SAAL program in 1976 coincided with Siza's return to the school - by his own choice as assistant professor of Construction. This return came at a time of expansion ${ }^{20}$, in which the curriculum was once again discussed and refined. Vertical and horizontal hierarchical links were established, between the various course years and course units and areas, with a direct relationship being established between Design and Drawing, while History and Construction also became "active parts of the design process" and were no longer mere "instruments of support."21

The teaching of Siza in the Construction course unit was paradigmatic of this approach to architectural design.
The question of construction was no longer broached merely as a technology in lectures, but rather in a practical way as a design exercise, which was treated an aspect of drawing in which, in the "placement of an idea, there is a simultaneous process in the material definition of a work in its form, in its construction and in its organization of the space". ${ }^{22}$

For Siza, an architectural idea "must contain all the alternatives for its own realization. An idea should not be abstract; it must have a floor, walls, openings", and in his classes, emphasis was not placed on the teaching of "all techniques", but, on the contrary, on the experience of developing a "process of authorial reflection on an idea and its images, its concreteness, of the capacity to imagine the materials"23. Siza would give his students a real intervention site and a small program, and after visiting the site the students had 4 hours to "sketch" a proposal on opaque paper, which was then critiqued as an architectural design. Siza strived for an aggregating logic with his design challenge: "the general notion is that very deep knowledge is absolutely necessary to build in stone, wood or concrete. But, first and foremost, it requires a logic." ${ }^{24}$

In 1978, faced with a new threat to the autonomy of the school from the central political powers, Siza clarified his position in his writings ${ }^{25}$ : he rejected training based on "plastic syntheses based on the information that knowledge of the human and exact sciences provides", advocating for an "awareness of disciplinary autonomy," where what is crucial to "understand and apprehend" is "the core of disciplinary methodological tools." He rejected a curriculum with "massive 


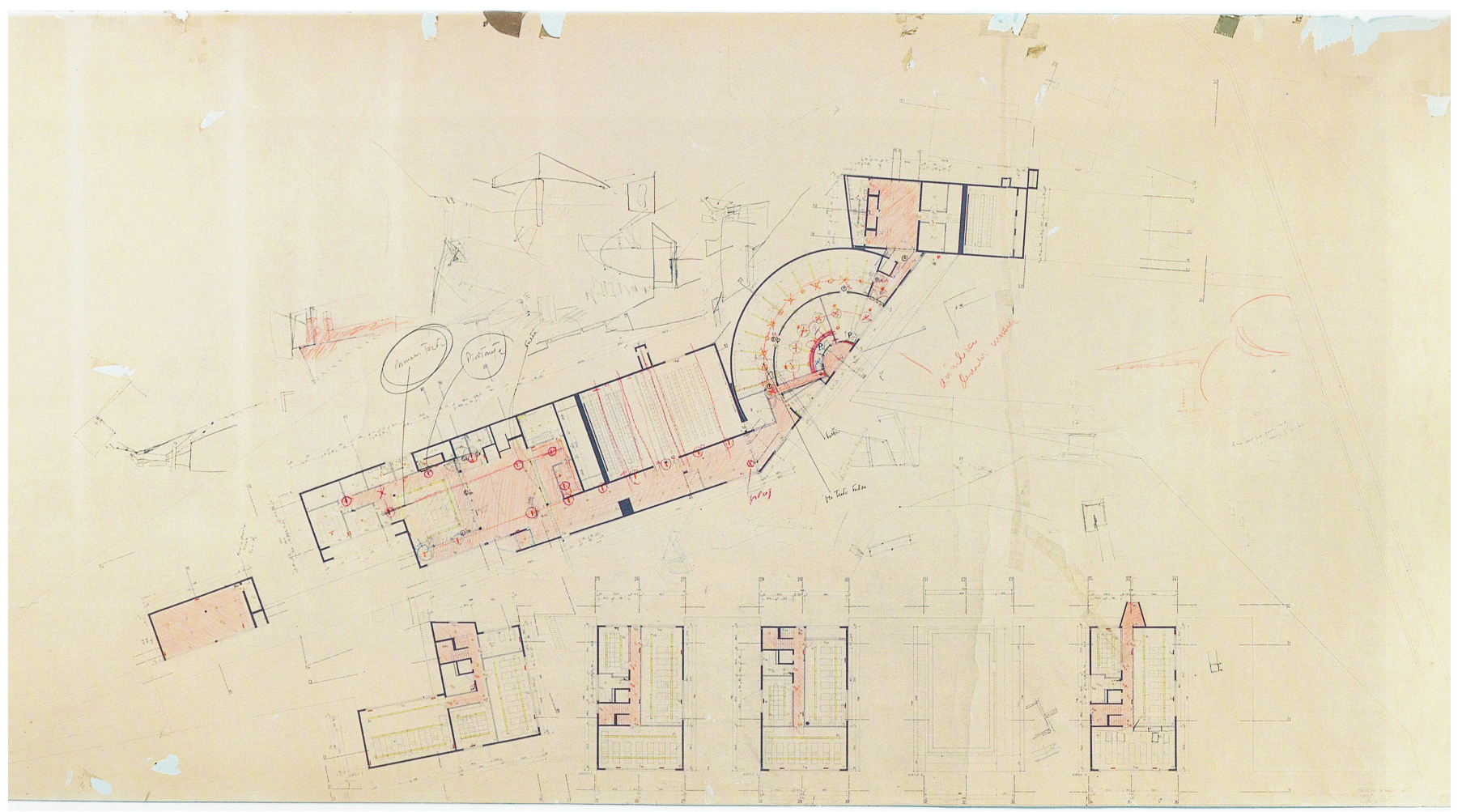

Figure 3. Álvaro Siza, FAUP, Second Floor Plan, 1989, Blueprint with pencil and coloured pencil. In Manuel Mendes (ed) Edifício da Faculdade de Arquitectura da Universidade do Porto: percursos do projecto (Porto:FAUP) 155

and numbing initial information" in favor of an initial "global and disciplinary, progressively conscientious and informed" approach, where the acquisition of knowledge would evolve from "fragments" guided by "a disciplinary will", which imprints the "ability to build a continuous fabric of applicable knowledge". This methodology would be crucial in the early years of the course, "where almost everything - not quite everything - [was] at stake".

He writes that in the Porto school there was a legacy that constituted a current, which required the protection and facilitation of all, as opposed to decontextualized copies, which were nothing but technocratic and provincial caricatures.

\section{0-90: NEW BUILDINGS}

"The examples of open spaces I know... I couldn't agree less". Álvaro Siza, $2001^{26}$

Between 1979 and 1984 the school of architecture separated from that of the Fine Arts and became its own faculty (FAUP).

Siza's own work moved him away from FAUP. However, he was to build the new facilities for the school, in two significant phases: the renovation of the main house, outbuildings and gardens of the Quinta da Póvoa estate (1983-86) and construction of the Carlos Ramos Pavilion (1985-86); and the construction of the new school building itself (1986-93).

For the first project, in addition to the "invisible" intervention for recovery of the houses and garden, he built a temporary pavilion to accommodate the school's immediate needs, before the new facilities could be built. The Carlos Ramos pavilion is a building that encloses under an internal void or patio, housing over two floors a series of classrooms that are simultaneously continuous and separate. In addition to the simultaneous distinction and enhancement of the context, reconstructing the place without losing its historical dimension, there is the affirmation of the school as a design "atelier," which seeks to reconcile the individual work and the collective dimension in the same space.

For the new building, the program for which was drawn up for 550 students ${ }^{27}$, the morphological option was to be for an urban presence in continuity with the pavilion-based environment of the gardens/ estate, whose ascendancy came from the historic facilities of the former architecture section at ESBAP in S. Lázaro.

There was a denial of the project's organization into "ample atelier spaces, almost without identification of year or class, Louis Khan, Artigas, Mies. No one thought this was good, we were in a period of recession: each atelier [was to] house the same number of students in a class and [was to] be an autonomous and closed spatial entity, though linked to a space for collective criticism." ${ }^{28}$ The teaching spaces are the design class spaces, one room per class and one building per year.

The Drawing class has its own room, at the top of the highest tower. History, Theory and Constructions did not have dedicated areas, using the design classrooms instead. And if the common spaces are of a "baroque fluidity," the design classrooms are "absolutely rigid" 
and "provocatively small."29

The morphology and typology give form to a hierarchy of time and program that is organized by curricular year and around classrooms/ ateliers for 15 students. The work is carried out at drawing tables, the placing of which is rigidly defined in the space of the room. The building can be seen as the materialization of a pedagogical project, in which there is a reciprocity between receptiveness and the rule of working in small teams (in the atelier) and the opening of social spaces, including the city and garden, where debate can be open and the playful dimension of open spaces sublimate life in society.

\section{A DIDACTIC TREND}

Álvaro Siza was present for more than half a century of the Porto school and was an important agent in moments of crisis, taking clear positions in defense of the school's autonomy.

Institutional autonomy to build and manage their own path, and disciplinary autonomy to find the methods and instruments necessary for practice and teaching. And also critical autonomy, in the sense that the responses to be provided by the school were to take into account the specificity of the historical process in which they were irremediably immersed.

Siza's position in relation to education is the same as in relation to professional practice. He has questioned imported processes (imported by the country and the discipline) and rebuilt himself reflecting on the practical experience of the group of colleagues closest to him. When he returned to school to teach Constructions, he culturalized technology, sublimating method and the logic of thought.

He writes that almost everything is decided in the first years of training. And advocates that only in the final years of training should the curriculum be open to choice by the students and that, in the first few years, the fragments of knowledge given by the various aspects of the syllabus be constantly united and given meaning by the design act, which corresponds, in its conception, to a holistic way of "thinking" architecture.

The design methodology proposed was abductive, both in rational and intuitive terms. It was the "authentic method," which does not evolve linearly from analysis to synthesis, but as in the example of Alvar Aalto is "a continuous, open, complex, and encompassing process." 30

The drawing, or rather the representation, was a non-linear research tool, with a "constant exchange between the rigor of the line and the sketches," in a movement of "communication" between the rigor of execution and the "ideas that are constantly modified with increasing knowledge of the program and the context." ${ }^{31}$ In this understanding, the Drawing, but also Theory, History and Constructions are tools for designing, for the conscious and sensitive transformation of the world, so when he teaches Constructions he subordinates technique to the disciplinary culture and has his students design.

Whether it was in design or in construction, Siza, with his pencil stored away, "listened more than he spoke." His role was that of a catalyst for a critical questioning that would unlock an individual design process. Always sensitive in his dealings with his students, he "avoided the scythe" so as not to "cut down what was still sprouting", but he also questioned, because "when I have an idea, it must contain all the alternatives for its realization." 32

The school spaces that Siza built for FAUP materialize the order, size, scale and the appropriate environment for this didactic approach to be established; but the designs are also a response that elaborates on the memory of São Lázaro and ESBAP, the place where that didactic method was born.

Siza advocated a specific tendency for the Porto school, but acknowledged that there were others, in other contexts or with other interpretations. At the same time in Lisbon a different course was taken. However, time has changed conditions, but Siza's proposals resonate significantly, especially with the entry of architecture into the area of academic research and when the discipline faces the further threat of importation of methodologies external to it and the fragmentation and denigration of its traditional methods, including design as a process of questioning and transforming reality.

\section{Notes}

1. Siza and some colleagues of his generation, including Alcino Soutinho, Arnaldo Araújo, António Menéres, Carlos Carvalho Dias, Cristiano Moreira, Duarte Castel Branco, Luís Pádua Ramos, Jorge Gigante, Bento Lousan, Raul Hestnes Ferreira, Sergio Fernandez and Sílvia Viana de Lima, was in the last group of students to be trained under the 1932 Reform curriculum.

2. Siza presented his CODA (Concurso para Obtenção de Diploma de Arquitecto) project, or Final Project for Architect's Diploma, in 1965 and passed with marks of 20 out of 20 . The CODA exam consisted of presenting a work, usually a design project, which was presented as final design project under the 1932 Study Plan.

3. With the Arts Education Reform of 1952-57, art school were given the category of higher education institutes, which would lead to several changes, including greater scholastic requirements for access, the introduction of the research lexicon and the reformulation of the curriculum with so-called "scientific"' disciplines, many of them taught outside of schools. EBAP changed its name to ESBAP.

4. Álvaro Siza, interview, in Raquel Paulino, ESBAP| FAUP. O Ensino da Arquitectura na Escola do Porto. Construção de um Projeto Pedagógico entre 1969 e 1984. (Porto: FAUP, doctoral thesis, 2013). In his first teaching experience in the 1960s, Siza followed the examples of Nuno Portas in Lisbon, who at the time experimented with the methodological proposals disseminated in Portugal ever since the Design Methods Conference of 1962 (London, Imperial College), under the influence of D.G. Thornley, G.H. Broadbent, C. Jones and C. Alexander.

5. Succeeding a series of assistants, such as Fernando Távora 
(1960-62), Arnaldo Araújo (1962-63) and José Carlos Loureiro (1963-65).

6. Nuno Portas (1934), architect, urbanist, teacher and essayist, was to be a fundamental figure in the affirmation and dissemination of Portuguese architecture. In 1962 Portas had begun his activity as a researcher in the National Laboratory of Civil Engineering, in the Department of Architecture. His work was to have repercussions in the two schools of architecture, namely through Portas himself and through figures such as Francisco Silva Dias, Óctavio Lixa Filgueiras, Arnaldo Araújo, Alexandre Alves Costa and Álvaro Siza.

7. Interview with Álvaro Siza, Gonçalo Canto Moniz, O Ensino Moderno da Arquitetura. A Reforma de 57 e as Escolas de Belas Artes em Portugal (1931-69) (Coimbra: FCTUCEDARQ, Doctoral thesis, 2011) 499.

8. In 1967 and 1968 he proposed that his students produce designs for a parish church (Aldoar) and for a motel (Coimbra). Gonçalo Canto Moniz (2011).

9. The protesters were Alfredo Viana de Lima, Álvaro Siza, Arnaldo Araújo, Cristiano Moreira, Duarte Castel Branco, Fernando Távora, Jorge Gigante, José Carlos Loureiro and Pedro Ramalho.

10. Carlos João Chambers de Oliveira Ramos (1897 - 1969), architect, urbanist and educator. Pioneer of the modern movement in Portugal, would have a decisive influence in the Porto School, as a teacher (1940-1952) and as director of the Fine Arts School (1952-1967).

11. Fernando Távora, Jorge Gigante, José Carlos Loureiro, Alfredo Viana de Lima, Álvaro Siza, Cristiano Moreira and Pedro Ramalho. January 1971. As in Anexo 5, 2. ${ }^{\circ}$ Comunicado dos ex-docentes dirigido à Escola de Arquitectura do Porto, in Escola Superior de Belas-Artes do Porto. Curso de Arquitectura. Relatório da Comissão Coordenadora. Ano Lectivo de 1969-70, FAUPCDUA/AE/TE/ADM-008.

12. Siza, together with Alexandre Alves Costa, Manuel Fernandes de Sá and Mário Brito, refused to return to the school due to a lack of guarantees, denouncing in a letter dated April 1971 to the director of ESBAP the failure to achieve the initial goals of the experimental regime and the blocking of the proposals of the Joint Evaluation Commission by the ministry.

13. Shared management by students and teachers would render the registration of absences and timetables and a curricular structure organized into years unnecessary, in favor of a system organized into "groups and themes" and the "structuring of the diverse subject matters around a central nucleus: the architectural design." Pedro Bandeira, Escola do Porto: Lado B - 1968-1978 (Uma História Oral), (Guimarães: CIAJG, 2014).

14. For further information see Jorge Figueira, Escola do Porto. Um Mapa Critico, (Coimbra: FCTUC- EDARQ, 2002).

15. Internship Report by Eduardo Souto de Moura, ESBAP, 1980, cited by Pedro Bandeira 2014:15.

16. For more information see Pedro Bandeira 2015.
17. SAAL "Serviço Apoio Ambulatório Local" [Local Mobile Support Service] was established by the Secretary of State for Housing and Urban Development, Nuno Portas, on July 31,1974 . Its aim was to support, through the various city councils, initiatives by poorly housed populations with a view to collaborating in the transformation of their own neighborhoods. In its brief period it formed an architectural and political project, involving direct participation, in an attempt to rapidly meet the needs of disadvantaged populations.

18. Namely Adalberto Dias, Eduardo Souto Moura, Graça Nieto, Manuela Sambade and Paula Cabral.

19. Brigada de São Vitor, "Proposta à Comissão Coordenadora do SAAL", in Livro Branco do SAAL 1974-1976. Volume 1 (Lisbon: Conselho Nacional do SAAL, 1976), 109.

20. By this time (1978), 150 students enrolled in the school in the first year, tripling the previous limit. The ongoing reorganization of the study plan (based on the "Architecture Course Meetings") made it possible to return to a more scholastic, hierarchical, individualized and organized education with absence and assessment systems.

21. Thus, the Constructions team reported on the design project works and the assessments could be discussed in class, year or cycle of learning, bringing together students and teachers of the various course units.

22. Álvaro Siza, interview with Raquel Paulino, Arquitetura 21 (Lisboa, n9, 2010) 32-35.

23. Álvaro Siza, interview, L'Architecture d'Aujourd'hui, no. 211, Álvaro Siza, Projets et réalisations 1970-1980, 1980, 1-3.

24. Álvaro Siza, L'Architecture d'Aujourd'hui, no. 211, 1980, 1-3.

25. Álvaro Siza, 1978. "Declaração ao Presidente da Assembleia de Representantes do Curso de Arquitetura da ESBAP”, de 4 de maio de 1978, in FAUP-CDUA/AE/TE/ADM-007.

26. Álvaro Siza, interview, ECDJ 4 (Coimbra: FCTUC-dARQ, 2001).

27. With the new complex, the school was able to increase student numbers from 350 to about 525. The Preliminary Program for the complex was presented by a "Technical Support Group" in 1983, having as support document the "Planning Standards for Higher Education Facilities" issued by UNESCO. The program comprised generally: 8 rooms for 15 students; 1 lecture hall for 160 pax; 2 lecture hall for 110 pax; 34 classrooms with drawing tables for 15 students; 1 room for drawing and model drawing to seat 100 pax; 4 laboratories; Museum, Library, Copy/Printing office, Secretariat, Snack Bar and Teacher Offices.

28. Alexandre Alves Costa, in Manuel Mendes (coord.), 2003. Edifício da Faculdade de Arquitectura da Universidade do Porto: percursos do projecto [The building of the Faculty of Architecture at Porto University: evolution of the design project]. (Porto: FAUP, 2003) 29-30.

29. Domingos Tavares, 2003, in Manuel Mendes (coord.), 2003. Edifício da Faculdade de Arquitectura da Universidade do 
Porto: percursos do projecto [The building of the Faculty of Architecture at Porto University: evolution of the design project]. (Porto: FAUP, 2003), 40.

30. Álvaro Siza, "Alvar Aalto: algumas referências à sua influência em Portugal", in Álvaro Siza, 01 Textos (Porto: Civilização, 2009) 212.

31. Álvaro Siza, L'Architecture d'Aujourd'hui, no. 211, 1980, 1-3.

32. Álvaro Siza, L'Architecture d'Aujourd'hui, no. 211, 1980, 1-3. 